\title{
The Relationship Between Parents' Education Levels to Fundamental Motor Skills Children's in Buttui Mentawai
}

\author{
Resi Marini ${ }^{*}$ and Anton Komaini ${ }^{2}$ \\ ${ }^{1,2}$ Faculty of Sports Sciences, Universitas Negeri Padang Padang, Indonesia \\ *Corresponding author. Email: resimarini7327@gmail.com
}

\begin{abstract}
The purpose of this study was to determine the relationship between the level of parental education with the basic movement skills of children in Buttui Mentawai Village. This research method uses a combined research method (Mixed Methods), which is a step of research by combining two forms of approach in research, namely qualitative and quantitative. This research was carried out in Buttui South Siberut Mentawai, West Sumatra in September 2019. The sample of the children was Buttui Hamlet, with 25 people aged between 5-6 years. For data on the level of education of parents taken informants from teachers who are in the hamlet of Buttui and Documentation Studies on Data that are in the auxiliary Community Health Center in the Buttui. In this study the data collection techniques used were participant observation, unstructured interviews, and documentation, as well as tests to measure the basic movement skills of Buttui children's. The results of the study concluded that there was no relationship between the level of education of parents with the basic movement skills of Buttui Hamlet children. The skills possessed by children in Buttui Village are very good, this is influenced by physical activity factors and the experience of the movements they do. All children in Buttui sub-village do physical activities following their parents, which are farming, hunting, gathering, fishing, and making sago.
\end{abstract}

Keywords: Parental education level, Fundamental Motor Skills

\section{INTRODUCTION}

Education can be interpreted as a process with certain methods so that people gain knowledge, understanding, and how to behave as needed. Education is meaningful as an attempt by humans to improve knowledge and understanding of science and life experiences. As is certain about the current picture of education is that parents, families, communities are as much a part of the education process as students, teachers, and staff are. In a broad sense education is all stages of the development of human abilities and behaviors, it must also use almost all life experiences [1].

According to RI Law No 20 of 2003 concerning the National education system article 1 paragraph 1 states that: Education is a conscious and planned effort to create an atmosphere of learning and learning process so that students actively develop their potential to have religious spiritual strength, self-control, personality, intelligence, noble character, and skills needed by himself, society, nation and country [2]. Education starts at home and whatever happens in it greatly influences development and learning. The greater the family's role in children's learning to eat, the more likely they are to get a quality education. Helping parents in child development, providing activities that parents can use to teach their children at home and supporting parents in their role as the child's first teacher, is a powerful way to succeed children and parents.

Family becomes a social context for children to learn to develop children's personality. The existence of families and their role in children's lives is very important. Therefore, the family must be a good example for children. The family is the first and foremost educational environment for children. The family functions as a cultural transmitter or mediator. The responsibility of parents in educating children is not only limited to children being able to maintain his life, but more than that is able to make sense of his life [3].

Morrison explained that: the family is the most important institution for children's education and development. Parents are the main educators of their children; they are the first teachers of their children. However, parents need educational assistance, and support to achieve this goal. Parents must guide and direct early childhood learning. Parents must be involved in every program their children follow, everyone must have knowledge and training in child 
mastery. Parents and other family members become collaborators for children's learning [4]. Family life as an educational institution, there is a process of mutual learning among family members. In this situation parents become the main role holders in the learning process of their children, especially when they are not yet an adult. Its activities include, through care, guidance, assistance, and real examples. In the field of relationships, children should be controlled [5].

Educational background and level of parental knowledge, influential correlated with the level of motor skills of children. The growth and development of children is needed by the provision of education and understanding of many things. All of these are basic needs for children's development and growth. To discuss basic needs in a sequential and logical way, needs can be grouped into physical needs, psychological needs and learning. There is a positive and convincing relationship between family involvement and its benefits for the child, which also includes the development of the child's motor skills.

Buttui Hamlet, Madobag Village, South Siberut District, Mentawai Islands Regency is one of the hamlets that is still inhabited by indigenous Mentawai tribes. The original Mentawai tribe here still maintains traditions, culture and local wisdom in carrying out daily life. The people here still use traditional clothes in their daily lives, their daily lives are very dependent on nature, the people work daily, that is farming, hunting, making sago, fishing and gathering medicine and poisons. According to Umar, et al. In daily life, the inhabitants of the Mentawai Pedalaman tribe carry out activities related to nature to sustain their lives, such as hunting, food processing, gathering medicine, and others. The inhabitants of the Mentawai Pedalaman tribe have a habit of hunting and farming [6]

Based on information obtained from the Pukesmas Assistant in this area, it was found that the level of education owned by parents on average here had no education. New education began with their children, as evidenced by several schools already standing in this place. Based on further surveys, that the basic movement skills of children in Buttui Village are very good, they are able to do locomotor, nonlocomotor and manipulative movements, they run, throw and climb. With this phenomenon there are things you want to know further whether there is a link between the educational background of parents with basic movement skills possessed by children of Buttui Village, Mentawai Regency.

\section{METHODS}

This research method uses a combined research method (Mixed Methods), which is a step of research by combining two forms of approach in research, namely qualitative and quantitative. Mixed research is a research approach that combines qualitative research with quantitative research [7]. This research was carried out in Buttui Hamlet in South Siberut Sub-District, Mentawai Regency, West Sumatra in September 2019. The sample of the children was Butti Hamlet, with 25 people aged between 5-6 years. For data on the level of education, parents are taken from informants from teachers in Buttui Hamlet and data from the Sub-District Public Health Center in the Hamlet. In this study the data collection techniques used were participant observation, unstructured interviews, and documentation, as well as tests to measure the basic movement skills of Buttui Hamlet children.

\section{RESULT AND DISCUSSION}

A. Result

1) Parental Education Level

Education in Buttui Hamlet is still very limited. The majority of these education levels are elementary school graduates. According to the results of an interview on one of the teachers at Tunas Bakti Bangsa who said that the limited availability of schools made the residents of Buttui Hamlet choose not to continue schooling. There are those who choose to marry after graduating from junior high school and some choose to work in the subdistrict center. For the sake of the progress of the population, the local government has currently held scholarships for the sons of Mentawai. Gradually through certain phases the same level of quality education will be achieved with other regions. It is expected that there are Vocational Middle Schools in each sub-district and High Schools for the Mentawai Islands and standardization of elementary schools. In order to continue the development of the Mentawai Islands, selective scholarships for students are programmed, which after completion of their studies are returned as potential workers to the Mentawai. The living habits of the Mentawai people scattered with traditional static life. The regional government has made a gradual effort to resettle the Mentawai people. In addition, there is a guidance for the welfare of isolated communities in the interior of Mentawai. Moving efforts in advancing the Menatawai islands have been started since 1972, this is also related to the intention to make Mentawai as a tourism area to complement the tourism potential in Sumatra.

From the results of the study it was found that in Buttui Hamlet the level of parental education was very minimal, on average parents in Buttui Hamlet did not attend school. Because here the parents of the children especially the mother (Buibui) from morning to evening are only busy working, from finding wood, to bringing 
water from the river home to drink, and also making sago to be processed into food.

2). Fundamental Motor Skills

Analysis of basic motion skills variables, obtained an average $=40.6$, standard deviation $=7.05$, the highest value $=45$ with a very good category and the lowest $=15$ with a very low category. For more information can be seen in the following table:

Table 1. Frequency Distribution of Basic Motion Skills

\begin{tabular}{|c|c|c|c|c|}
\hline No & $\begin{array}{l}\text { Interval } \\
\text { Class }\end{array}$ & $F_{\text {absolut }}$ & $F_{\text {relatif }}$ & Category \\
\hline 1 & $15-20$ & 1 & 4 & $\begin{array}{l}\text { Very } \\
\text { Less }\end{array}$ \\
\hline 2 & $21-26$ & 1 & 4 & Less \\
\hline 3 & $27-32$ & 1 & 4 & Enough \\
\hline 4 & $33-38$ & 2 & 8 & Medium \\
\hline 5 & $39-44$ & 11 & 8 & Good \\
\hline 6 & $\begin{array}{l}45 \text { and } \\
\text { above }\end{array}$ & 9 & 36 & $\begin{array}{l}\text { Very } \\
\text { Good }\end{array}$ \\
\hline & amount & 25 & 100 & \\
\hline
\end{tabular}

Based on the above table, it can be concluded that from 25 early childhood children who have the results of basic movement skills data for 15-20 interval classes is 1 person (4\%). Then the interval class 21-26 were 1 person (4\%), the interval class $27-32$ were 1 person (4\%), the interval class 33-38 were 2 people (8\%), and the interval class $39-44$ was 11 people ( $8 \%$ ), while the 45-50 class interval is 9 people $(39 \%)$. For more details on the variable early childhood movement skills in Buttui Village can be seen in the following figure:

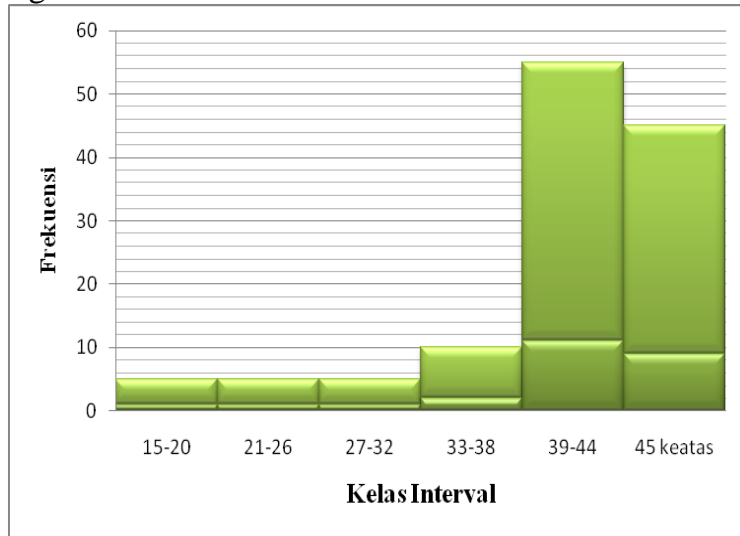

Figure 1. Fundamenta Motor Skills Data Histogram

\section{B. Discuss}

Based on the results of the study it was found that there was no correlation between the level of parental education with the basic movement skills of the children of Buttui Hamlet. This can be seen from the results of the study which states that almost all the parents of the children sampled did not go to school and only a few people graduated from elementary school, but their children's basic basic skills were very good. It was concluded that there was no relationship between the level of parental education with basic mobility skills in Buttui Hamlet. The skills possessed by children in Buttui Village are very good, this is influenced by physical activity factors and the experience of the movements they do. All children in Buttui sub-village do physical activities following their parents, which are farming, hunting, gathering, fishing, and making sago. These activities make the basic movement skills of children well trained. They are able to do motor movements well, with the experience of movement that they get while following the activities of their parents. According to the Sultan, et al there were a number of activities carried out by the Siberut Mentawai community, among others, the sago harvesting activity that was carried out was still traditional and carried out with family members, next was making poison arrows, and making native Mentawai clothing from bark (loincloth) [8 ] Mahmudah further explained that the Mentawai indigenous people their lives depend on nature, so they do not have a place to live and work permanently, like and able to create something good, beautiful and useful such as making boats and arrows for hunting and subbah (traditional buckets) for catching fish.

\section{CONCLUSION}

There is no relationship between the level of parental education with basic mobility skills in the hamlet of Buttui. The skills possessed by children in Buttui Village are very good, this is influenced by physical activity factors and the experience of the movements they do. All children in Buttui sub-village do physical activities following their parents, which are farming, hunting, gathering, fishing, and making sago. These activities make the basic movement skills of children well trained. They are able to do motor movements well, with the experience of movement that they get while following the activities of their parents.

\section{REFERENCES}

[1] Muhibbin, Syah (2011).Psikologi Pendidikan. Bandung: PT. Remaja Rosdakarya

[2] Undang-Undang Republik Indonesia No 20 Tahun 2003 tentang Sistem Pendidikan Nasional Pasal 1, ayat 1

[3] Yusuf, Syamsu (2008).Psikologi Perkembangan Anak dan Remaja. Bandung: PT. Remaja Rosdakarya 
[4] Morrison, George S. Dasar-Dasar Pendidikan Usia Dini (PAUD). Jakarta: PT. Indeks, 2012.

[5] Al Tridhonanto,(2014).Mengembangkan Pola Asuh Demokratis. Jakarta: PT. Gramedia

[6] Umar, Laydi Yulifitrya. 2017. Aktivitas Fisik Suku Mentawai Pedalaman Kabupaten Kepulauan Mentawai Provinsi Sumatera Barat. Jurnal Performa Olahraga Vol 2 No 02.

[7] Creswell, J.W. 2010.Research design: Pendekatan kualitatif, kuantitatif, dan mixed. (Achmad Fawaid, Pengalih bahasa). Yogyakarta: Pustaka Pelajar

[8] Sultan Fairuzy Ramadhan, Destario Metusala, Mawar ta Onida Sinaga, 2017. Potensi Pengembangan Tradisi Etnobotani Sebagai
Ekowisata Berkelanjutan: Studi Kasus Suku Mentawai di Pulau Siberut, Kepulauan Mentawai. Jurnal Pro-Life Volume 4 Nomor 2

[9] Mahmudah Nur, Sikerei In The Story: Tracing Mentawai Cultural Identity 1. Jurnal Masyarakat \& Budaya, Volume 21 No. 1 Tahun 2019

[10] Pemerintah Kabupaten Kepulauan Mentawai. 2014. Kabupaten Kepulauan Mentawai Dalam Angka. Mentawai.

[11] Pokja Sanitasi Kepulaan Mentawai. 2014. Buku Putih Sanitasi Kepulauan Mentawai. Di unduh tanggal 25 Dessember 2019. Padang. 